\title{
Relationship between energy balance and metabolic profiles in plasma and milk of dairy cows in early lactation
}

\author{
Wei Xu, ${ }^{1,2} \odot$ Jacques Vervoort, ${ }^{2} \odot$ Edoardo Saccenti, ${ }^{3}$ Bas Kemp, ${ }^{1} \odot$ Renny J. van Hoeij, ${ }^{1} \odot$ \\ and Ariette T. M. van Knegsel ${ }^{1 *}$ (D) \\ ${ }^{1}$ Adaptation Physiology Group, Department of Animal Sciences, Wageningen University and Research, PO Box 338, 6700 AH, Wageningen, \\ the Netherlands. \\ ${ }^{2}$ Laboratory of Biochemistry, Wageningen University and Research, PO Box 338, $6700 \mathrm{AH}$, Wageningen, the Netherlands \\ ${ }^{3}$ Laboratory of Systems and Synthetic Biology, Wageningen University and Research, Stippeneng 4, 6708 WE, Wageningen, the Netherlands
}

\begin{abstract}
Negative energy balance in dairy cows in early lactation is related to alteration of metabolic status. However, the relationships among energy balance, metabolic profile in plasma, and metabolic profile in milk have not been reported. In this study our aims were: (1) to reveal the metabolic profiles of plasma and milk by integrating results from nuclear magnetic resonance (NMR) with data from liquid chromatography triple quadrupole mass spectrometry (LC-MS); and (2) to investigate the relationship between energy balance and the metabolic profiles of plasma and milk. For this study 24 individual dairy cows (parity $2.5 \pm 0.5$; mean \pm standard deviation) were studied in lactation wk 2 . Body weight (mean \pm standard deviation; $627.4 \pm 56.4$ $\mathrm{kg})$ and milk yield $(28.1 \pm 6.7 \mathrm{~kg} / \mathrm{d}$; mean \pm standard deviation) were monitored daily. Milk composition (fat, protein, and lactose) and net energy balance were calculated. Plasma and milk samples were collected and analyzed using LC-MS and NMR. From all plasma metabolites measured, 27 were correlated with energy balance. These plasma metabolites were related to body reserve mobilization from body fat, muscle, and bone; increased blood flow; and gluconeogenesis. From all milk metabolites measured, 30 were correlated with energy balance. These milk metabolites were related to cell apoptosis and cell proliferation. Nine metabolites detected in both plasma and milk were correlated with each other and with energy balance. These metabolites were mainly related to hyperketonemia; $\beta$-oxidation of fatty acids; and one-carbon metabolism. The metabolic profiles of plasma and milk provide an in-depth insight into the physiological pathways of dairy cows
\end{abstract}

Received October 22, 2019.

Accepted January 5, 2020.

*Corresponding author: ariette.vanknegsel@wur.nl in negative energy balance in early lactation. In addition to the classical indicators for energy balance (e.g., $\beta$-hydroxybutyrate, acetone, and glucose), the current study presents some new metabolites (e.g., glycine in plasma and milk; kynurenine, panthothenate, or arginine in plasma) in lactating dairy cows that are related to energy balance and may be of interest as new indicators for energy balance.

Key words: metabolomics, mammary gland, liquid chromatography-mass spectrometry, nuclear magnetic resonance

\section{INTRODUCTION}

In dairy cows in early lactation, elevated energy requirements for milk production combined with a relatively low energy intake can result in a negative energy balance (NEB; Bell, 1995; de Vries and Veerkamp, 2000). High-producing dairy cows or dairy cows with an extreme peripartum reduction in energy intake (e.g., overconditioned cows) are at particularly high risk for severe NEB (Grummer et al., 2004). Severe NEB is associated with a higher risk of metabolic disorders (Grummer, 1993) and compromised health and fertility (Butler and Smith, 1989; Collard et al., 2000). To compensate for the energy deficit in early lactation, dairy cows mobilize body reserves (Collard et al., 2000) such as body fat and muscle protein (van der Drift et al., 2012). Traditionally, the concentration of metabolites in plasma and in milk have been used to diagnose NEB and associated metabolic disorders. For example, altered free fatty acid profiles in plasma are related to NEB (Gross et al., 2011b), and BHB in plasma or in milk is a biomarker for subclinical ketosis in dairy cows (Whitaker et al., 1993; Geishauser et al., 1998).

Over the past decade, the combination of metabolomics and advanced statistical methods have made it possible to identify and quantify low-abundance molecules from biofluids. Using integrated analysis, complex correlation matrices can be obtained by combining 
results from liquid chromatography triple quadrupole mass spectrometry (LC-MS) and nuclear magnetic resonance (NMR) measurements with complementary data from plasma, milk, or urine (Crockford et al., 2008; Maher et al., 2013). In dairy cows, Klein et al. (2013) reported the detection of amino acids and carboxylic acids in plasma and milk using GC-MS and NMR and discussed the metabolites related to ketosis. Maher et al. (2013) reported that the majority of milk metabolites were not correlated with their concentrations in plasma. Biomarkers for heat stress in cows have been identified in blood plasma samples from LC-MS and NMR (Tian et al., 2016). To our knowledge, the correlation between the metabolic profiles of plasma and milk samples has been studied only to a limited extent (Ilves et al., 2012; Klein et al., 2013; Maher et al., 2013). Milk metabolic profiles are potentially of interest as indicators for (systemic) metabolic profiles or energy balance in lactating dairy cows.

In the current study, we hypothesized that the metabolic profiles of cows based on plasma and milk might differ in their relation to energy balance. The aims of this study were to reveal the metabolic profiles of cows based on plasma and milk samples by combining the results of LC-MS and NMR, and to investigate the relationship between energy balance and the metabolic profiles of cows based on plasma and milk samples.

\section{MATERIALS AND METHODS}

\section{Animals and Sample Collection}

The experimental protocol was approved by the Institutional Animal Care and Use Committee of Wageningen University, and the study was conducted at the dairy campus research farm (WUR Livestock Research, Lelystad, the Netherlands). The original experiment was designed to study the consequences of lowering dietary energy levels for cows with a $0-\mathrm{d}$ dry period length (DPL) compared to cows with a 0 -d DPL and standard energy levels or cows with a 30-d DPL and standard energy levels, as described previously (van Hoeij et al., 2017). In the current study, we included only cows with standard dietary energy levels (6.4 MJ of net energy $/ \mathrm{kg}$ of DM and $1 \mathrm{~kg} / \mathrm{d}$ of standard concentrate), 0- or 30-d DPL, and parity 2 or 3. In addition, all samples were collected from cows that originated from the same batch. Earlier, we reported the relationship between milk metabolites identified through LC-MS and the energy balance of 31 dairy cows in lactation wk 2 and 7 (Xu et al., 2018); we used the LC-MS data obtained from milk samples of 24 cows in lactation wk 2 again in the current study.
Prepartum, cows with a 0-d DPL received a lactation ration based on grass silage and corn silage (6.4 MJ of $\mathrm{NE}_{\mathrm{L}} / \mathrm{kg}$ of DM). Cows with a $30-\mathrm{d} \mathrm{DPL}$ received a dry cow ration based on grass silage, corn silage, and wheat straw (5.4 MJ of $\mathrm{NE}_{\mathrm{L}} / \mathrm{kg}$ of DM). Postpartum, all cows received the same basal lactation ration as provided to lactating cows prepartum, plus additional concentrates. Postpartum, concentrate supply increased stepwise by $0.3 \mathrm{~kg} / \mathrm{d}$, up to $8.5 \mathrm{~kg} / \mathrm{d}$ at 28 DIM. Body weight, milk yield, and feed intake were recorded daily. During lactation, cows were milked twice daily at $\sim 0600$ and $\sim 1800$ $h$.

Milk samples for analysis of fat, protein, and lactose percentage (ISO 9622, Qlip, Zutphen, the Netherlands) were collected 4 times per week (Tuesday afternoon, Wednesday morning, Wednesday afternoon, and Thursday morning). Milk samples were analyzed as a pooled sample per cow per week and used to calculate average fat, protein, and lactose yield per week. Plasma samples for metabolomics studies were collected on Thursday after the morning milking (average $10.4 \pm 1.8 \mathrm{DIM}$ ), between 3 and $1 \mathrm{~h}$ before the morning feeding. Milk samples for metabolomics studies were collected on Friday morning after the blood sampling. All samples were collected and stored at $-20^{\circ} \mathrm{C}$ until analysis. Milk production traits were averaged per week.

\section{Energy Intake and Energy Balance}

Roughage and concentrate were supplied separately, and daily intakes were recorded per individual cow using roughage intake control troughs (Insentec, Marknesse, the Netherlands). Energy balance was calculated per week according to the Dutch net energy evaluation (VEM) system as the difference between energy intake and the estimated net energy requirements for maintenance and milk yield (Van Es, 1975; CVB, 2005). According to the VEM system, the daily requirement for maintenance is $42.4 \mathrm{VEM} / \mathrm{kg}^{0.75}$ of BW; the requirement for milk yield is $442 \mathrm{VEM} / \mathrm{kg}$ of fat- and proteincorrected milk. Energy intake and energy balance are expressed in $\mathrm{kJ} / \mathrm{kg}^{0.75}$ per day, where $\mathrm{kg}^{0.75}$ indicates metabolic body weight (Van Es, 1975).

\section{Sample Preparation}

Sample preparation in LC-MS and NMR was performed as described previously (Lu et al., 2013). Blood plasma and milk samples were first thawed to room temperature. Briefly, the fat layer of the milk was removed with the addition of deuterated chloroform and subsequent centrifugation $(13,523 \times g, 15 \mathrm{~min}$; Centrifuge 5424; Eppendorf, Hamburg, Germany) to isolate 
the water-soluble fraction. Then, $175 \mu \mathrm{L}$ of milk serum or blood plasma was mixed with $175 \mu \mathrm{L}$ of phosphate buffer ( $\mathrm{pH}$ 7.0), and these samples were filtered to remove protein using a Pall $0.5 \mathrm{~mL} 10-\mathrm{kDa}$ cutoff spin filter (Millipore Corp., Billerica, MA) with centrifugation at $13,523 \times g$ for $15 \mathrm{~min}$.

\section{Measurement in LC-MS and Data Preprocessing}

Quantification of metabolites has been described previously (Xu et al., 2018). Measurements were performed using a triple quadrupole mass spectrometer (LCMS-8040; Shimadzu, Kyoto, Japan) using the PFPP (pentafluorophenylpropyl) method as described previously (Matsubara et al., 2014; Suzuki et al., 2016). The sample injection volume used was $1 \mu \mathrm{L}$, and a single analysis took $25 \mathrm{~min}$. From LC-MS spectra, metabolites were regarded as reliably identified when more than $60 \%$ of observations in all samples showed a reliable value for a certain metabolite.

\section{Measurement in NMR and Data Preprocessing}

Prepared samples were measured using an Avance III NMR spectrometer (Bruker, Billerica, MA) with a $600-\mathrm{MHz} / 54-\mathrm{mm}$ UltraShielded Plus magnet equipped with a CryoPlatform cryogenic cooling system, a BCU05 cooling unit, and an ATM automatic tuning and matching unit. Measurements were conducated at 300 $\mathrm{K}$. Then, 1-dimensional nuclear Overhauser enhancement spectroscopy (NOESY) spectra were obtained. Baseline corrections, alignment, and calibration to internal maleic acid was done for all spectra. Assignment of metabolite resonances was performed using published literature, the Human Metabolome Database version 2.0 online library (http://hmdb.ca/), and internal standards.

\section{Integrated Analysis and Software}

Previously, we detected no effect of DPL on milk metabolites ( $\mathrm{Xu}$ et al., 2018), so we did not include DPL in the analysis of relationships between energy balance and metabolic profile in plasma or milk. In addition, only healthy cows (i.e., without diagnosis of clinical disease) were included in the analysis. Integrated analysis of the LC-MS and NMR data was applied as described previously (Crockford et al., 2006; Maher et al., 2013). Briefly, Pearson correlation was applied to any 2 columns in a matrix. Pearson correlation coefficients $(r)$ and corresponding $P$-values were obtained with the function cor.test in $\mathrm{R}$ (version 3.4.3; https:// www.r-project.org/).

\section{RESULTS}

\section{Milk Production and Energy Balance}

In lactation wk 2, the mean (SD in parentheses) BW of the 24 dairy cows was 627.4 (56.4) kg; milk yield was $28.1(6.7) \mathrm{kg} / \mathrm{d}$; fat- and protein-corrected milk production was $32.3(7.3) \mathrm{kg} / \mathrm{d}$; milk fat yield was $1.4(0.4)$ $\mathrm{kg} / \mathrm{d}$; milk protein yield was $1.1(0.2) \mathrm{kg} / \mathrm{d}$; and milk lactose yield was $1.3(0.3) \mathrm{kg} / \mathrm{d}$. The energy balance of dairy cows was $-180.0(219.1) \mathrm{kJ} / \mathrm{kg}^{0.75} \cdot \mathrm{d}$, which was negatively correlated with milk yield and milk production traits: $r$-values ranged from -0.78 to -0.91 (Supplemental Figure S1; https://doi.org/10.3168/jds .2019-17777).

\section{Measurement by LC-MS and NMR and Integrated Analysis}

We measured plasma and milk samples of 24 dairy cows in lactation wk 2 using both LC-MS and NMR. In LC-MS spectra, 97 metabolites were initially targeted for both plasma and milk samples. From the LC-MS spectra of plasma and milk, respectively, 43 metabolites (Supplemental Table S1; https://doi.org/10.3168/jds .2019-17777) and 41 metabolites (Supplemental Table S2; https://doi.org/10.3168/jds.2019-17777) could be reliably detected. In the NMR spectra (resolution 0.01 ppm), bins that were correlated with energy balance were selected and the corresponding NMR resonances (peaks) were specifically integrated by carefully selecting peaks that did not show overlap with neighboring peaks in the NMR spectra. A total of 15 metabolites in plasma and 10 metabolites in milk were detected using both NMR and LC-MS. If one metabolite was detected in both measurements, data obtained from NMR were used in further analysis. Through the combination of LC-MS and NMR (Figure 1), a total of 56 and 65 metabolites were identified from plasma and milk samples, respectively. Of these, 38 were detected in both blood plasma and milk. In the NMR spectra of plasma, isobutyrate, 1,2-propanediol, and $\alpha$-ketoisovalerate were tentatively assigned; in milk, $\beta$-alanine was tentatively assigned. Detailed information on these metabolites in blood plasma and milk is presented in Supplemental Tables S1 and S2.

\section{Relation of Energy Balance with Metabolic Profiles in Plasma and in Milk}

Energy balance was correlated with several metabolites in milk, in plasma, or in both $(P<0.05)$. Based on their correlation with energy balance, metabolites were assigned to 1 of 3 groups: (1) energy balance correlated 
with metabolites both in plasma and in milk (Figure 2A); (2) energy balance correlated with metabolites in plasma only (Figures 2B and D); or (3) energy balance correlated with metabolites in milk only (Figures 2C and D). In total, 9 metabolites (acetone, acetylcarnitine, aspartate, BHB, carnitine, creatinine, glycine, hydroxyproline, and thymidine) were correlated with energy balance in both plasma and milk, with $r$-values ranging from -0.80 to 0.57 for plasma and from -0.79 to 0.59 for milk (Figure 2A). These 9 metabolites had a correlation between their concentrations in plasma and in milk, with $r$-values ranging from 0.49 to 0.92 . Of the 53 detected and identified metabolites in plasma, 24 were correlated with energy balance in dairy cows (Figures $2 \mathrm{~A}, \mathrm{~B}$, and $\mathrm{D}$ ), with $r$-values ranging from -0.80 to 0.84 . Of the 64 detected and identified metabolites in milk, 30 were correlated with energy balance in dairy cows (Figures 2A, C, and D), with $r$-values ranging from -0.79 to 0.71 . In total, 10 and 12 metabolites correlated with energy balance were uniquely detected from plasma and milk samples, respectively (Figure 2D).

\section{DISCUSSION}

\section{Metabolites in Plasma and in Milk Related to Energy Balance}

Of all detected amino acids and their derivatives, glycine showed the most striking correlation with energy

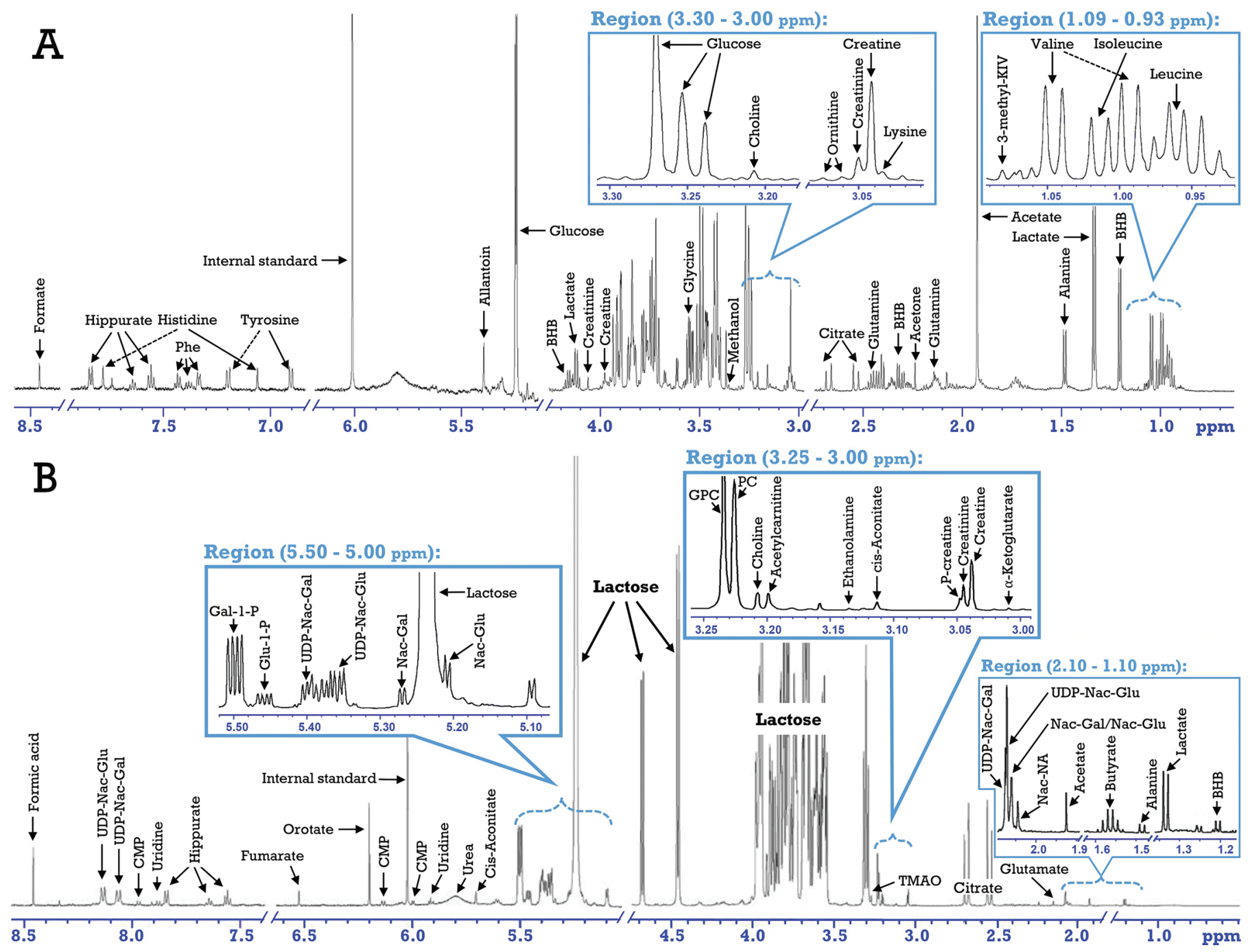

Figure 1. Metabolites identified from nuclear magnetic resonance spectra in (A) plasma and (B) milk of dairy cows in early lactation. 3-methyl-KIV = 3-methyl-2-oxovaleric acid; CMP = cytidine monophosphate; Gal-1-P = galactose-1-phosphate; Glu-1-P = glucose-1-phosphate; GPC $=$ glycerophosphocholine; Nac-Gal $=N$-acetylgalactose $;$ Nac-Glu $=N$-acetyl-glucosamine; Nac-NA $=N$-acetyl-neuraminic acid; PC $=$ phosphocholine; $\mathrm{P}$-creatine $=$ phosphocreatine; TMAO $=$ trimethylamine $N$-oxide; UDP $=$ uridine diphosphate. 


\section{Plasma Metabolites}

Milk Metabolites

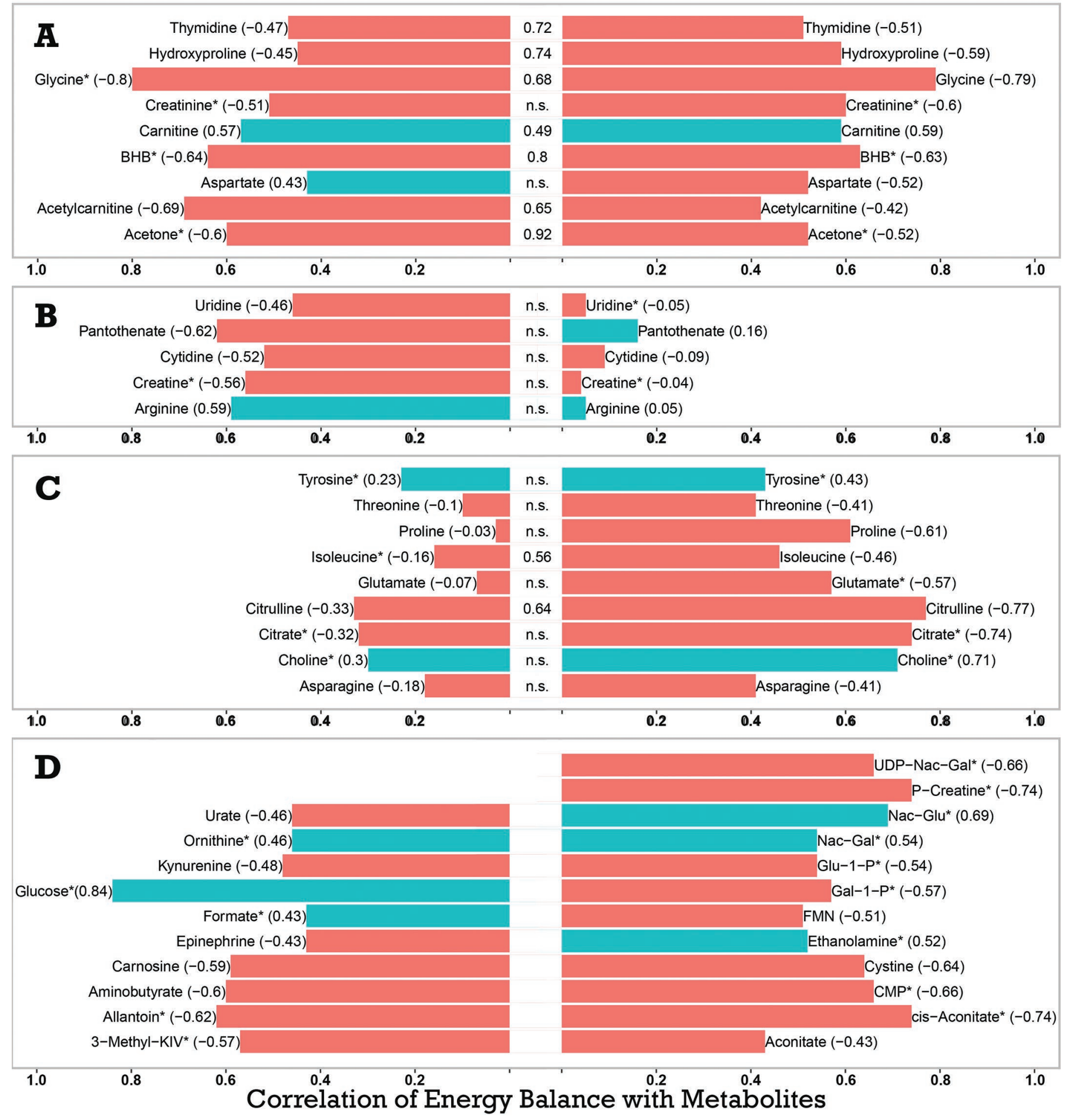

Figure 2. Pearson correlations for energy balance with metabolites in lactation wk 2. (A) Metabolites in both plasma and milk that have a correlation with energy balance. (B) Metabolites in plasma, but not in milk, that are correlated with energy balance. (C) Metabolites in milk, but not in plasma, that are correlated with energy balance. (D) Unique metabolites in plasma or in milk that are correlated with energy balance. Cyan bars represent positive correlations; red bars represent negative correlations. Metabolites detected by nuclear magnetic resonance are marked by an asterisk. Values in parentheses are Pearson correlations. Values in middle column are the $r$-values of metabolites between their concentrations in plasma and in milk. 3-methyl-KIV $=3$-methyl-2-oxovaleric acid; CMP $=$ cytidine monophosphate; FMN $=$ flavin mononucleotide; Gal-1-P = galactose-1-phosphate; Glu-1-P = glucose-1-phosphate; Nac-Gal = $N$-acetylgalactose; Nac-Glu $=N$-acetylglucosamine; $\mathrm{P}$-creatine $=$ phosphocreatine; UDP $=$ uridine diphosphate 
balance in both plasma $(r=-0.80)$ and milk $(r=$ -0.79 ). This was consistent with previous studies, in which dairy cows had increased glycine concentration in plasma (Doepel et al., 2002; Luo et al., 2019) and in milk (Klein et al., 2010) around calving. In dairy cows in NEB, increased glycine concentration in plasma was suggested to be related to the breakdown of muscle protein (Doepel et al., 2002), or to the de novo synthesis of glycine from threonine and serine (Amelio et al., 2014). In our study, glycine in plasma was positively correlated with its concentration in milk $(r=0.68)$, which could be related to transfer mechanisms between blood and the mammary gland in dairy cows (Raggio et al., 2006). Glycine in both plasma and milk could be used as an indicator for energy balance and metabolic status in dairy cows (Shibano et al., 2005; Xu et al., 2018). As will be discussed in more detail below, we propose that increased concentrations of glycine in both plasma and milk could be due to an increase in one-carbon metabolic processes, in which choline is converted into glycine. Choline can provide methyl groups for cell proliferation in the mammary gland (Wu et al., 2013).

In earlier studies, the ratio of glycine to alanine (Gly: Ala) in plasma was used as a biomarker for malnutrition in dairy cows in early lactation (Shibano et al., 2005). In our study, energy balance was negatively correlated with Gly:Ala in plasma $(r=-0.72)$ and in milk $(r=$ -0.82 ); the correlation between Gly:Ala in plasma and Gly:Ala in milk was 0.85 . However, alanine itself was not correlated with energy balance, probably because of the dual nature of alanine in the glucose-alanine cycle in muscle and hepatocytes (Felig, 1973). Based on our observations, we conclude that the previously proposed Gly:Ala depends more on the fluctuation of glycine levels than on changes in the concentration of alanine, and that monitoring glycine levels is more indicative of changes in energy balance than monitoring Gly:Ala.

Energy balance was negatively correlated with thymidine in both plasma $(r=-0.47)$ and milk $(r=$ $-0.51)$. Thymidine plays an important role in DNA synthesis (Shields et al., 1990). Thymidine in the mammary gland can be speculated to originate from plasma, which is supported by the positive correlation $(r=$ 0.72 ) between thymidine in plasma and in milk. Energy balance was negatively correlated with hydroxyproline in both plasma $(r=-0.45)$ and milk $(r=-0.59)$. In early lactation, dairy cows have an increase in calcium and magnesium requirements, and they mobilize minerals from bone to maintain the mineral balance in plasma (Goff, 2008). Released from bone degradation, hydroxyproline in plasma could indicate the balance between bone formation and bone degradation (Price et al., 1980). Hydroxyproline and proline are the major amino acids of collagen, which is the main structural protein in connective tissues and in bone (Marshall and Bangert, 2008). Both hydroxyproline and proline were present in high amounts in the milk of cows in NEB $(r$ $=-0.61$ ). The high concentration of hydroxyproline and proline in milk could indicate that the compounds could be used to form collagen proteins in connective tissues for cell renewal in the mammary gland, and possibly also in the uterus, rumen, and muscle (Wu et al., 2011). The epithelial cells of the mammary gland are permeable to plasma hydroxyproline, supported by the strong positive correlation $(r=0.74)$ between hydroxyproline in plasma and in milk.

Energy balance was negatively correlated with acetone and BHB in both plasma and milk. As well, the correlation between acetone in plasma and in milk was 0.92, and between BHB in plasma and in milk was 0.80. In early lactation, body fat mobilization and high requirements for glucose for lactose synthesis coincide with high plasma concentrations of ketone bodies (Kessel et al., 2008). Plasma ketone bodies (acetone and BHB) are well known to be related to the incomplete $\beta$-oxidation of mobilized body fat (Cooke et al., 2007; Zhou et al., 2016), resulting in ketosis. Acetone and $\mathrm{BHB}$, either in plasma or in milk, have been used to diagnose ketosis or subclinical ketosis in cows in early lactation (Sato, 2009; LeBlanc, 2010), in line with our finding that energy balance was correlated with ketone bodies in both plasma and milk. Acetone and BHB could be used not only for energy supply (Peterson et al., 2012), but also for the synthesis of short- and medium-chain fatty acids in the mammary gland (Bauman and Griinari, 2003). The results of the current study could indicate a direct relationship between ketone bodies in plasma and in milk, supported by the arteriovenous difference of BHB and acetoacetate plus acetate in the mammary gland (Schwalm et al., 1972). This confirms the value of milk ketone body levels as an indicator of incomplete oxidation of fatty acids and ketosis at systemic level. The correlation of carnitine in plasma with its concentration in milk was 0.49 , and the correlation of acetylcarnitine in plasma with its concentration in milk was 0.65 , which is suggested to be related to the role of carnitine and acetylcarnitine in fat metabolism (Nelson et al., 2008). Carnitine and acetylcarnitine play important roles in transporting activated long-chain fatty acids from the cytosol into the peroxisome and mitochondria (Wanders et al., 2016). These processes occur in both the liver and mammary gland cells in lactating cows (Carlson et al., 2007). Moreover, in dairy cows, acylcarnitines play a role in peripartum adaptations in lipid metabolism and the occurrence of metabolic disorders such as excessive lipolysis (Humer et al., 2016) or reduced insulin sensitivity (Rico et al., 
2018). The correlations of carnitine, acetylcarnitine, $\mathrm{BHB}$, and acetone in plasma with their concentrations in milk, and their positive correlations with energy balance, indicate the oxidation of fatty acids in the liver and the use of fatty acids as an energy source and for milk fat synthesis in the mammary glands of dairy cows in NEB.

Energy balance was negatively correlated with citrate in milk $(r=-0.74)$. Citrate not only plays a role in the tricarboxylic acid cycle, but also forms one of the main products in buffer systems in milk (Linzell et al., 1976). In our previous study, milk citrate was an indicator of energy balance in dairy cows (Xu et al., 2018). In the mammary gland, epithelial cells are impermeable to citrate (Linzell et al., 1976), and the concentration of citrate in milk could reflect its role in fat synthesis in the mammary gland itself.

\section{Metabolites in Plasma Related to Energy Balance}

In the current study, several metabolites - arginine, pantothenate, allantoin, glucose, and epinephrine were related to energy balance in plasma, but they were not related to energy balance in milk. For instance, energy balance was positively correlated with arginine in plasma $(r=0.59)$, but not in milk $(P>0.05)$. In the urea cycle (Figure 3), arginine metabolism is related not only to nitrogen (urea) metabolism, but also to nitric oxide production. Nitric oxide is a major vasodilator factor (Kim and $\mathrm{Wu}, 2009$ ). The low level of arginine in dairy cows in NEB could indicate that nitric oxide in plasma increases with a concomitant increase in blood flow used for a greater supply of nutrients to support milk production in the mammary gland. The increased blood flow also facilitates the absorption of nutrients from the small intestine (Stentoft et al., 2015). In the current study, energy balance was negatively correlated with plasma pantothenate $(r=-0.62)$ and plasma allantoin $(r=-0.70)$. Both pantothenate and allantoin are nutrients for dairy cows that are derived from the feed source or produced by ruminal microbes (Giesecke et al., 1994; National Research Council, 2001).

Energy balance was positively correlated with plasma glucose $(r=0.80)$, which was in line with earlier studies that plasma glucose decreases after parturition (Hammon et al., 2009; Gross et al., 2011a). Dairy cows use glucose not only as an energy source (Bauman and Currie, 1980), but also as a precursor for synthesizing lactose in milk (Kleiber et al., 1955) and as a methyl donor via one-carbon metabolism for DNA and RNA synthesis during cell renewal (Tedeschi et al., 2013; Amelio et al., 2014). Plasma glucose concentration is regulated by insulin, which was low for dairy cows in early lactation, as we reported previously (van Hoeij et al., 2017). For the 24 cows in the current study, plasma insulin was $11.1 \pm 6.7 \mathrm{U} / \mathrm{mL}$ in wk 2 of lactation. Low insulin concentrations decrease the uptake of glucose by peripheral tissue and facilitate uptake of glucose by the mammary gland, which has insulin-independent glucose transporters (Laarveld et al., 1981). In the mammary gland, one molecule of glucose is converted to galactose, which is combined with another molecule of glucose to synthesize lactose (Kuhn et al., 1980). In our study, low glucose and insulin concentrations in plasma during NEB could mirror the high priority of mammary gland for glucose (Bauman, 2000; Drackley et al., 2001). A shortage of glucose could be compensated for by gluconeogenesis. For example, branched-chain amino acids (isoleucine, leucine, and valine) can be used for gluconeogenesis in liver ( $\mathrm{Li}$ et al., 2015). In the current study, however, none of branched-chain amino acids in plasma were correlated with energy balance $(P<0.05)$.

Body fat metabolism accounts for most of the energy lost or gained in dairy cows (Komaragiri et al., 1998), but muscle protein is also mobilized (Komaragiri et al., 1998; Corbin and Zeisel, 2012). In plasma, energy balance was correlated negatively with plasma creatine $(r$ $=-0.56)$ and plasma creatinine $(r=-0.51)$, indicating that energy balance is associated with the mobilization of muscle protein in dairy cows in NEB. Our results were in line with those of a previous study, indicating that mobilized muscle protein is related to higher concentrations of plasma creatine and creatinine in cows with low energy balance (Castillo et al., 2006).

Epinephrine in plasma is one of the hormones correlated with energy balance $(r=-0.43)$, which is consistent with the observation that infusion of epinephrine could increase free fatty acids and glucose in plasma (Brockman and Laarveld, 1986; Fröhli and Blum,

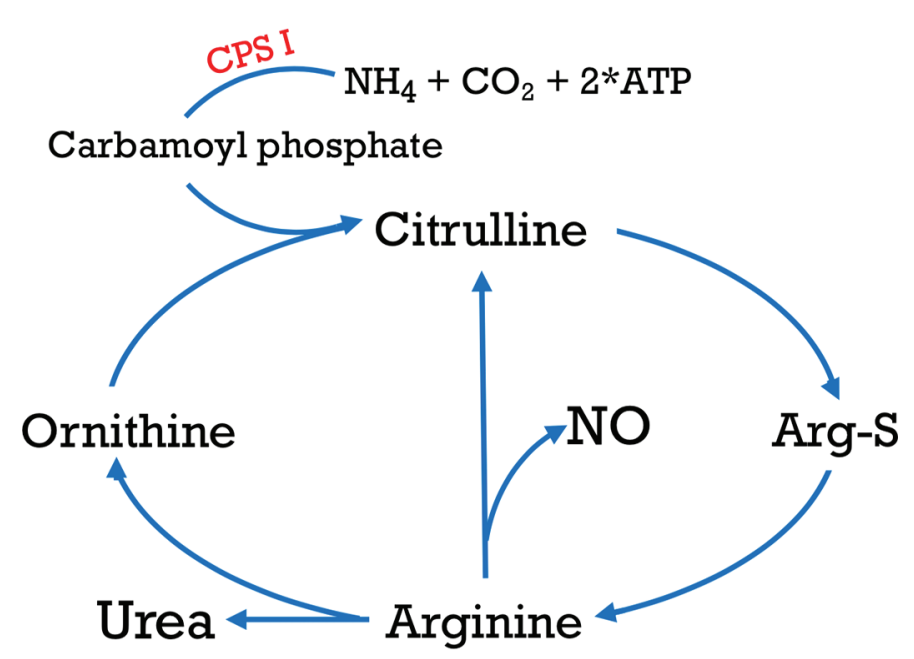

Figure 3. Nitric oxide production from the urea cycle. Arg-S = argininosuccinate; CPS I = carbamoyl phosphate synthetase 1 . 
1988). Plasma glucose levels are low in dairy cows in NEB (Brockman and Laarveld, 1986). In addition to its role in body fat mobilization in early lactation (Herdt, 2000), epinephrine is known to stimulate gluconeogenesis in the liver, helping to compensate for the low glucose levels to some extent (Whitton et al., 1978). In mammals, epinephrine is synthesized via tyrosine in the adrenal gland (Udenfriend and Wyngaarden, 1956). In the current study, tyrosine was detected in plasma, and had a positive but relatively weak correlation $(r=0.23)$ with energy balance. Further studies are needed to unravel the relationships among tyrosine, epinephrine, and energy balance in dairy cows in early lactation.

\section{Metabolites in Milk Related to Energy Balance}

Milk metabolites can originate from several sources, including being transferred from blood; leaked from damaged somatic cells and bacteria present in milk; or secreted from mammary epithelial cells (Davis et al., 2004; Sundekilde et al., 2013). The correlation between energy balance and metabolites in milk rather than in plasma could indicate metabolism in the mammary gland of dairy cows in lactation wk 2 .

Energy balance was negatively correlated with galactose-1-phosphate $(r=-0.57)$ and glucose-1-phosphate $(r=-0.54)$ in milk. Both galactose-1-phosphate and glucose-1-phosphate are 2 intracellular intermediates in lactose synthesis (Linzell and Peaker, 1971). It has been suggested that increased levels of galactose-1-phosphate and glucose-1-phosphate in dairy cows in NEB result from the leakage of cellular content due to cell apoptosis in the mammary gland in early lactation ( $\mathrm{Lu}$ et al., 2013). Cell apoptosis happens in coordination with cell proliferation, which is indicated by the $65 \%$ increase in total DNA used for meiosis around $10 \mathrm{~d}$ pre- and postpartum (Akers, 2016). The increased nucleotide metabolism could also explain the positive correlation between energy balance and milk cytidine monophosphate $(r=-0.66)$ and thymidine $(r=-0.51)$. The positive correlation between thymidine in plasma and its concentration in milk $(r=0.72)$ indicates that the source of thymidine in the mammary gland is plasma. In addition to the synthesis of nucleotides, the correlation of energy balance with milk ethanolamine $(r=$ $0.52)$ and milk glycerophosphocholine $(r=0.40 ; P=$ 0.05 ) could be related to the process of cell membrane synthesis (Kennedy and Weiss, 1956). In the context of cell membrane synthesis, the correlation of energy balance with acetyl-derivatives, including $N$-acetylgalactosamine $(r=0.54), N$-acetylglucosamine $(r=0.69)$, and UDP- $N$-acetylgalactosamine $(r=-0.66)$, could be related to their roles in the glycosylation pathways of proteins.
In an earlier study (Klein et al., 2012), a ratio of glycerophosphocholine to phosphocholine in milk of less than 2.5 was related to an increased risk of ketosis. In our study, energy balance was positively correlated with the ratio of glycerophosphocholine to phosphocholine $(r=0.49 ; P=0.02)$ and choline in milk $(r=0.71)$. Choline acts as a methyl donor for biological processes involving the folate cycle, redox balance status, and cell renewal (Friesen et al., 2007), and choline is regarded as a limiting nutrient for transition dairy cows (Grummer, 2012). The supplementation of rumen-protected choline can increase milk production (Pinotti et al., 2003; Zahra et al., 2006), which is possibly due to the facilitating effect of choline in exporting fat into the plasma from the liver in cows (Piepenbrink and Overton, 2003; Cooke et al., 2007). Based on this hypothesis, dairy cows supplemented with rumen-protected choline should have low plasma BHB and free fatty acids. In our study, choline in plasma was not correlated with plasma BHB or acetone $(P>0.05)$, a finding that was supported by studies showing that supplemented rumen-protected choline is not correlated with a decreased plasma BHB and free fatty acids in dairy cows (Guretzky et al., 2006; Zahra et al., 2006). We speculate that the majority of choline is consumed in the mammary gland to facilitate cell proliferation in early lactation.

\section{Integrated Analysis with a Combination of NMR and LC-MS}

In our studies, a total of 15 metabolites in plasma and 10 metabolites in milk were detected using both NMR and LC-MS. Some of these metabolites had correlations $>0.85$ between NMR and LC-MS measurements in plasma [alanine $(r=0.95)$, choline $(r=0.87)$, creatine $(r=0.87)$, creatinine $(r=0.85)$, glutamine $(r=$ $0.85)$, glycine $(r=0.96)$, lactate $(r=0.95)$, and valine $(r=0.95)]$ and in milk [(acetyl-carnitine $(r=0.97)$, choline $(r=0.98)$, cytidine monophosphate $(r=0.99)$, and uridine $(r=0.97)]$. The high correlations between NMR and LC-MS for the intensity of these metabolites indicated that both NMR and LC-MS measurements were performed with the desired quality, and that the data sets were reliably interpreted.

To our knowledge, our study is the first to report metabolic profiles in plasma and in milk, and their correlation with estimated energy balance in dairy cows in early lactation. It is known that cows with the same estimated energy balance and same lactation stage can differ in metabolic status (Kessel et al., 2008). This inconsistency between energy balance and metabolic status could be due to inaccuracy or assumptions made to estimate energy balance, which could be relevant for extremely low NEB values (Van Knegsel et al., 2012); 
or individual variations in physiological adaptation to the start of lactation and NEB (Kessel et al., 2008). In the case of the latter, a metabolomics profile in early lactation could be more informative about the physiological status of the cow and subsequent adjustment of management strategies than information on energy balance alone.

\section{CONCLUSIONS}

In addition to the classical indicators for energy balance (e.g., BHB, acetone, and glucose), the current study presents some new metabolites (e.g. glycine in plasma and milk or kynurenine, panthothenate, or arginine in plasma) in lactating dairy cows that are related to energy balance and may be of interest as new indicators of energy balance. Further validation studies, as well as the development of technical applications, are essential to facilitate their practical use.

\section{ACKNOWLEDGMENTS}

The authors thank the China Scholarship Council (CSC, China) for financial support of the PhD study of the first author. The authors thank the staff of the Dairy Campus (Lelystad, the Netherlands) and Gerrit Remmelink for their assistance during the experiment. The authors have not stated any conflicts of interest.

\section{REFERENCES}

Akers, R. M. 2016. Lactation and the Mammary Gland. John Wiley \& Sons, Hoboken, NJ.

Amelio, I., F. Cutruzzolá, A. Antonov, M. Agostini, and G. Melino. 2014. Serine and glycine metabolism in cancer. Trends Biochem. Sci. 39:191-198. https://doi.org/10.1016/j.tibs.2014.02.004.

Bauman, D. 2000. Regulation of nutrient partitioning during lactation: Homeostasis and homeorhesis revisited. Pages 311-328 in Ruminant Physiology: Digestion, Metabolism, Growth and Reproduction. CABI, Wallingford, UK.

Bauman, D. E., and W. B. Currie. 1980. Partitioning of nutrients during pregnancy and lactation: A review of mechanisms involving homeostasis and homeorhesis. J. Dairy Sci. 63:1514-1529. https:// doi.org/10.3168/jds.s0022-0302(80)83111-0.

Bauman, D. E., and J. M. Griinari. 2003. Nutritional regulation of milk fat synthesis. Annu. Rev. Nutr. 23:203-227. https://doi.org/ 10.1146/annurev.nutr.23.011702.073408.

Bell, A. W. 1995. Regulation of organic nutrient metabolism during transition from late pregnancy to early lactation. J. Anim. Sci. 73:2804-2819. https://doi.org/10.2527/1995.7392804x.

Brockman, R. P., and B. Laarveld. 1986. Hormonal regulation of metabolism in ruminants: A review. Livest. Prod. Sci. 14:313-334. https://doi.org/10.1016/0301-6226(86)90012-6.

Butler, W. R., and R. D. Smith. 1989. Interrelationships between energy balance and postpartum reproductive function in dairy cattle. J. Dairy Sci. 72:767-783. https://doi.org/10.3168/jds.S0022 $-0302(89) 79169-4$

Carlson, D. B., J. W. McFadden, A. D'Angelo, J. C. Woodworth, and J. K. Drackley. 2007. Dietary L-carnitine affects periparturient nutrient metabolism and lactation in multiparous cows. J. Dairy Sci. 90:3422-3441. https://doi.org/10.3168/jds.2006-811.
Castillo, C., J. Hernández, I. Valverde, V. Pereira, J. Sotillo, M. L. Alonso, and J. L. Benedito. 2006. Plasma malonaldehyde (MDA) and total antioxidant status (TAS) during lactation in dairy cows. Res. Vet. Sci. 80:133-139. https://doi.org/10.1016/j.rvsc.2005.06 .003 .

Collard, B. L., P. J. Boettcher, J. C. Dekkers, D. Petitclerc, and L. R. Schaeffer. 2000. Relationships between energy balance and health traits of dairy cattle in early lactation. J. Dairy Sci. 83:2683-2690. https://doi.org/10.3168/jds.S0022-0302(00)75162-9.

Cooke, R. F., N. Silva del Rio, D. Z. Caraviello, S. J. Bertics, M. H. Ramos, and R. R. Grummer. 2007. Supplemental choline for prevention and alleviation of fatty liver in dairy cattle. J. Dairy Sci. 90:2413-2418. https://doi.org/10.3168/jds.2006-028.

Corbin, K. D., and S. H. Zeisel. 2012. Choline metabolism provides novel insights into nonalcoholic fatty liver disease and its progression. Curr. Opin. Gastroenterol. 28:159-165. https://doi.org/10 .1097/MOG.0b013e32834e7b4b.

Crockford, D. J., E. Holmes, J. C. Lindon, R. S. Plumb, S. Zirah, S. J. Bruce, P. Rainville, C. L. Stumpf, and J. K. Nicholson. 2006. Statistical heterospectroscopy, an approach to the integrated analysis of NMR and UPLC-MS data sets: Application in metabonomic toxicology studies. Anal. Chem. 78:363-371. https://doi.org/10 $.1021 / \mathrm{ac} 051444 \mathrm{~m}$.

Crockford, D. J., A. D. Maher, K. R. Ahmadi, A. Barrett, R. S. Plumb, I. D. Wilson, and J. K. Nicholson. 2008. 1H NMR and UPLC-MSE statistical heterospectroscopy: Characterization of drug metabolites (xenometabolome) in epidemiological studies. Anal. Chem. 80:6835-6844. https://doi.org/10.1021/ac801075m.

CVB. 2005. Veevoedertabel. Gegevens over Chemische Samenstelling, Verteerbaarheid en Voederwaarde van Voedermiddelen. CVB, Lelystad, the Netherlands.

Davis, S. R., V. C. Farr, C. G. Prosser, G. D. Nicholas, S.-A. Turner, J. Lee, and A. L. Hart. 2004. Milk L-lactate concentration is increased during mastitis. J. Dairy Res. 71:175-181. https://doi.org/ 10.1017/s002202990400007X.

de Vries, M. J., and R. F. Veerkamp. 2000. Energy balance of dairy cattle in relation to milk production variables and fertility. J. Dairy Sci. 83:62-69. https://doi.org/10.3168/jds.S0022-0302(00)74856-9.

Doepel, L., H. Lapierre, and J. J. Kennelly. 2002. Peripartum performance and metabolism of dairy cows in response to prepartum energy and protein intake. J. Dairy Sci. 85:2315-2334. https://doi .org/10.3168/jds.S0022-0302(02)74312-9.

Drackley, J. K., T. R. Overton, and G. N. Douglas. 2001. Adaptations of glucose and long-chain fatty acid metabolism in liver of dairy cows during the periparturient period. J. Dairy Sci. 84:E100-E112. https://doi.org/10.3168/jds.S0022-0302(01)70204-4.

Felig, P. 1973. The glucose-alanine cycle. Metabolism 22:179-207. https://doi.org/10.1016/0026-0495(73)90269-2.

Friesen, R. W., E. M. Novak, D. Hasman, and S. M. Innis. 2007. Relationship of dimethylglycine, choline, and betaine with oxoproline in plasma of pregnant women and their newborn infants. J. Nutr. 137:2641-2646. https://doi.org/10.1093/jn/137.12.2641.

Fröhli, D. M., and J. W. Blum. 1988. Nonesterified fatty acids and glucose in lactating dairy cows: diurnal variations and changes in responsiveness during fasting to epinephrine and effects of betaadrenergic blockade. J. Dairy Sci. 71:1170-1177. https://doi.org/ 10.3168/jds.S0022-0302(88)79671-X.

Geishauser, T., K. Leslie, D. Kelton, and T. Duffield. 1998. Evaluation of five cowside tests for use with milk to detect subclinical ketosis in dairy cows. J. Dairy Sci. 81:438-443. https://doi.org/10.3168/ jds.S0022-0302(98)75595-X.

Giesecke, D., L. Ehrentreich, M. Stangassinger, and F. Ahrens. 1994. Mammary and renal excretion of purine metabolites in relation to energy intake and milk yield in dairy cows. J. Dairy Sci. 77:23762381. https://doi.org/10.3168/jds.S0022-0302(94)77180-0.

Goff, J. P. 2008. The monitoring, prevention, and treatment of milk fever and subclinical hypocalcemia in dairy cows. Vet. J. 176:50-57. https://doi.org/10.1016/j.tvjl.2007.12.020.

Gross, J., H. A. van Dorland, R. Bruckmaier, and F. Schwarz. 2011a. Performance and metabolic profile of dairy cows during a lactational and deliberately induced negative energy balance with sub- 
sequent realimentation. J. Dairy Sci. 94:1820-1830. https://doi .org/10.3168/jds.2010-3707.

Gross, J., H. A. van Dorland, R. M. Bruckmaier, and F. J. Schwarz. 2011b. Milk fatty acid profile related to energy balance in dairy cows. J. Dairy Res. 78:479-488. https://doi.org/10.1017/ S0022029911000550.

Grummer, R. 2012. Choline: a limiting nutrient for transition dairy cows. Pages $22-27$ in Proc. Cornell Nutr. Conf., Syracuse, NY. Cornell University, Ithaca, NY.

Grummer, R. R. 1993. Etiology of lipid-related metabolic disorders in periparturient dairy cows. J. Dairy Sci. 76:3882-3896. https://doi .org/10.3168/jds.S0022-0302(93)77729-2.

Grummer, R. R., D. G. Mashek, and A. Hayirli. 2004. Dry matter intake and energy balance in the transtion period. Vet. Clin. North Am. Food Anim. Pract. 20:447-470. https://doi.org/10.1016/j .cvfa.2004.06.013.

Guretzky, N. A. J., D. B. Carlson, J. E. Garrett, and J. K. Drackley. 2006. lipid metabolite profiles and milk production for holstein and jersey cows fed rumen-protected choline during the periparturient period. J. Dairy Sci. 89:188-200. https://doi.org/10.3168/jds .S0022-0302(06)72083-5.

Hammon, H. M., G. Stürmer, F. Schneider, A. Tuchscherer, H. Blum, T. Engelhard, A. Genzel, R. Staufenbiel, and W. Kanitz. 2009 Performance and metabolic and endocrine changes with emphasis on glucose metabolism in high-yielding dairy cows with high and low fat content in liver after calving. J. Dairy Sci. 92:1554-1566. https://doi.org/10.3168/jds.2008-1634.

Herdt, T. H. 2000. Ruminant adaptation to negative energy balance: influences on the etiology of ketosis and fatty liver. Vet. Clin. North Am. Food Anim. Pract. 16:215-230. https://doi.org/10 .1016/s0749-0720(15)30102-X.

Humer, E., A. Khol-Parisini, B. U. Metzler-Zebeli, L. Gruber, and Q. Zebeli. 2016. Alterations of the lipid metabolome in dairy cows experiencing excessive lipolysis early postpartum. PLoS One 11:e0158633. https://doi.org/10.1371/journal.pone.0158633.

Ilves, A., H. Harzia, K. Ling, M. Ots, U. Soomets, and K. Klik. 2012. Alterations in milk and blood metabolomes during the first months of lactation in dairy cows. J. Dairy Sci. 95:5788-5797. https://doi .org/10.3168/jds.2012-5617.

Kennedy, E. P., and S. B. Weiss. 1956. The function of cytidine coenzymes in the biosynthesis of phospholipides. J. Biol. Chem. 222:193-214.

Kessel, S., M. Stroehl, H. Meyer, S. Hiss, H. Sauerwein, F. Schwarz, and R. Bruckmaier. 2008. Individual variability in physiological adaptation to metabolic stress during early lactation in dairy cows kept under equal conditions. J. Anim. Sci. 86:2903-2912. https:// doi.org/10.2527/jas.2008-1016.

Kim, S. W., and G. Wu. 2009. Regulatory role for amino acids in mammary gland growth and milk synthesis. Amino Acids 37:8995. https://doi.org/10.1007/s00726-008-0151-5.

Kleiber, M., A. L. Black, M. A. Brown, C. F. Baxter, J. R. Luick, and F. H. Stadtman. 1955. Glucose as a precursor of milk constituents in the intact dairy cow. Biochim. Biophys. Acta 17:252-260. https: //doi.org/10.1016/0006-3002(55)90357-7.

Klein, M. S., M. F. Almstetter, N. Nurnberger, G. Sigl, W. Gronwald, S. Wiedemann, K. Dettmer, and P. J. Oefner. 2013. Correlations between milk and plasma levels of amino and carboxylic acids in dairy cows. J. Proteome Res. 12:5223-5232. https://doi.org/10 $.1021 / \mathrm{pr} 4006537$.

Klein, M. S., M. F. Almstetter, G. Schlamberger, N. Nurnberger, K. Dettmer, P. J. Oefner, H. H. Meyer, S. Wiedemann, and W. Gronwald. 2010. Nuclear magnetic resonance and mass spectrometrybased milk metabolomics in dairy cows during early and late lactation. J. Dairy Sci. 93:1539-1550. https://doi.org/10.3168/jds.2009 $-2563$.

Klein, M. S., N. Buttchereit, S. P. Miemczyk, A.-K. Immervoll, C. Louis, S. Wiedemann, W. Junge, G. Thaller, P. J. Oefner, and W. Gronwald. 2012. NMR metabolomic analysis of dairy cows reveals milk glycerophosphocholine to phosphocholine ratio as prognostic biomarker for risk of ketosis. J. Proteome Res. 11:1373-1381. https://doi.org/10.1021/pr201017n.
Komaragiri, M. V., D. Casper, and R. Erdman. 1998. Factors affecting body tissue mobilization in early lactation dairy cows. 2. Effect of dietary fat on mobilization of body fat and protein. J. Dairy Sci. 81:169-175. https://doi.org/10.3168/jds.S0022-0302(98)75564-X.

Kuhn, N. J., D. T. Carrick, and C. J. Wilde. 1980. Lactose synthesis: The possibilities of regulation. J. Dairy Sci. 63:328-336. https:// doi.org/10.3168/jds.S0022-0302(80)82934-1.

Laarveld, B., D. Christensen, and R. Brockman. 1981. The effect of insulin on net metabolism of glucose and amino acids by the bovine mammary gland. Endocrinology 108:2217-2221. https://doi.org/ 10.1210/endo-108-6-2217.

LeBlanc, S. 2010. Monitoring metabolic health of dairy cattle in the transition period. J. Reprod. Dev. 56(Suppl.):S29-S35. https://doi .org/10.1262/jrd.1056s29.

Li, L. O., T. J. Grevengoed, D. S. Paul, O. Ilkayeva, T. R. Koves, F. Pascual, C. B. Newgard, D. M. Muoio, and R. A. Coleman. 2015. Compartmentalized acyl-CoA metabolism in skeletal muscle regulates systemic glucose homeostasis. Diabetes 64:23-35. https://doi .org/10.2337/db13-1070.

Linzell, J. L. T. B. Mepham, and M. Peaker. 1976. The secretion of citrate into milk. J. Physiol. 260:739-750. https://doi.org/10.1113/ jphysiol.1976.sp011541.

Linzell, J., and M. Peaker. 1971. Mechanism of milk secretion. Physiol. Rev. 51:564-597. https://doi.org/10.1152/physrev.1971.51.3.564.

Lu, J., E. Antunes Fernandes, A. E. Paez Cano, J. Vinitwatanakhun, S. Boeren, T. van Hooijdonk, A. van Knegsel, J. Vervoort, and K. A. Hettinga. 2013. Changes in milk proteome and metabolome associated with dry period length, energy balance, and lactation stage in postparturient dairy cows. J. Proteome Res. 12:3288-3296. https://doi.org/10.1021/pr4001306.

Luo, Z. Z., L. H. Shen, J. Jiang, Y. X. Huang, L. P. Bai, S. M. Yu, X. P. Yao, Z. H. Ren, Y. X. Yang, and S. Z. Cao. 2019. Plasma metabolite changes in dairy cows during parturition identified using untargeted metabolomics. J. Dairy Sci. 102:4639-4650. https://doi .org/10.3168/jds.2018-15601.

Maher, A. D., B. Hayes, B. Cocks, L. Marett, W. J. Wales, and S. J. Rochfort. 2013. Latent biochemical relationships in the blood-milk metabolic axis of dairy cows revealed by statistical integration of 1H NMR spectroscopic data. J. Proteome Res. 12:1428-1435. https://doi.org/10.1021/pr301056q.

Marshall, W. J., and S. K. Bangert. 2008. Clinical Biochemistry: Metabolic and Clinical Aspects. Elsevier Health Sciences, Amsterdam, the Netherlands.

Matsubara, A., Y. Izumi, S. Nishiumi, M. Suzuki, T. Azuma, E. Fukusaki, T. Bamba, and M. Yoshida. 2014. Supercritical fluid extraction as a preparation method for mass spectrometry of dried blood spots. J. Chromatogr. B Analyt. Technol. Biomed. Life Sci. 969:199-204. https://doi.org/10.1016/j.jchromb.2014.08.013.

Nelson, D. L., A. L. Lehninger, and M. M. Cox. 2008. Lehninger Principles of Biochemistry. Macmillan, Stuttgart, Germany.

NRC. 2001. Nutrient Requirements of Dairy Cattle. 7th rev. ed. Natl Acad. Press, Washington, DC.

Peterson, S. E., P. Rezamand, J. Williams, W. Price, M. Chahine, and M. McGuire. 2012. Effects of dietary betaine on milk yield and milk composition of mid-lactation Holstein dairy cows. J. Dairy Sci. 95:6557-6562. https://doi.org/10.3168/jds.2011-4808.

Piepenbrink, M. S., and T. R. Overton. 2003. Liver metabolism and production of cows fed increasing amounts of rumen-protected choline during the periparturient period. J. Dairy Sci. 86:17221733. https://doi.org/10.3168/jds.S0022-0302(03)73758-8.

Pinotti, L., A. Baldi, I. Politis, R. Rebucci, L. Sangalli, and V. Dell'Orto. 2003. Rumen-protected choline administration to transition cows: Effects on milk production and vitamin E status. J. Vet. Med. A Physiol. Pathol. Clin. Med. 50:18-21. https://doi .org/10.1046/j.1439-0442.2003.00502.x.

Price, P. A., J. G. Parthemore, and L. J. Deftos. 1980. New biochemical marker for bone metabolism. Measurement by radioimmunoassay of bone GLA protein in the plasma of normal subjects and patients with bone disease. J. Clin. Invest. 66:878-883. https://doi .org/10.1172/JCI109954. 
Raggio, G., S. Lemosquet, G. E. Lobley, H. Rulquin, and H. Lapierre. 2006. Effect of casein and propionate supply on mammary protein metabolism in lactating dairy cows. J. Dairy Sci. 89:4340-4351. https://doi.org/10.3168/jds.S0022-0302(06)72481-X.

Rico, J. E., Y. Zang, N. J. Haughey, A. G. Rius, and J. W. McFadden. 2018. Short communication: Circulating fatty acid acylcarnitines are elevated in overweight periparturient dairy cows in association with sphingolipid biomarkers of insulin resistance. J. Dairy Sci. 101:812-819. https://doi.org/10.3168/jds.2017-13171.

Sato, H. 2009. Increased blood concentration of isopropanol in ketotic dairy cows and isopropanol production from acetone in the rumen. Anim. Sci. J. 80:381-386. https://doi.org/10.1111/j.1740 -0929.2009.00649.x.

Schwalm, J. W., R. Waterman, G. E. Shook, and L. H. Schultz. 1972. Blood metabolite interrelationships and changes in mammary gland metabolism during subclinical ketosis. J. Dairy Sci. 55:5864. https://doi.org/10.3168/jds.S0022-0302(72)85432-8.

Shibano, K.-i., S. Kawamura, R. Hakamada, and Y. Kawamura. 2005. The relationship between changes in serum glycine and alanine concentrations in non-essential amino acid and milk production in the transition period in dairy cows. J. Vet. Med. Sci. 67:191-193. https://doi.org/10.1292/jvms.67.191.

Shields, A. F., K. Lim, J. Grierson, J. Link, and K. A. Krohn. 1990. Utilization of labeled thymidine in DNA synthesis: Studies for PET. J. Nucl. Med. 31:337-342.

Stentoft, C., B. A. Røjen, S. K. Jensen, N. B. Kristensen, M. Vestergaard, and M. Larsen. 2015. Absorption and intermediary metabolism of purines and pyrimidines in lactating dairy cows. Br. J. Nutr. 113:560-573. https://doi.org/10.1017/S0007114514004000.

Sundekilde, U. K., N. A. Poulsen, L. B. Larsen, and H. C. Bertram. 2013. Nuclear magnetic resonance metabonomics reveals strong association between milk metabolites and somatic cell count in bovine milk. J. Dairy Sci. 96:290-299. https://doi.org/10.3168/ jds.2012-5819.

Suzuki, M., S. Nishiumi, T. Kobayashi, T. Azuma, and M. Yoshida. 2016. LC-MS/MS-based metabolome analysis detected changes in the metabolic profiles of small and large intestinal adenomatous polyps in Apc Min/+ mice. Metabolomics 12:68. https://doi.org/ 10.1007/s11306-016-0988-7.

Tedeschi, P. M., E. K. Markert, M. Gounder, H. Lin, D. Dvorzhinski, S. Dolfi, L. L. Chan, J. Qiu, R. DiPaola, K. Hirshfield, L. G. Boros, J. R. Bertino, Z. N. Oltvai, and A. Vazquez. 2013. Contribution of serine, folate and glycine metabolism to the ATP, NADPH and purine requirements of cancer cells. Cell Death Dis. 4:e877. https: //doi.org/10.1038/cddis.2013.393.

Tian, H., N. Zheng, W. Wang, J. Cheng, S. Li, Y. Zhang, and J. Wang. 2016. Integrated metabolomics study of the milk of heat-stressed lactating dairy cows. Sci. Rep. 6:24208. https://doi.org/10.1038/ srep24208.

Udenfriend, S., and J. B. Wyngaarden. 1956. Precursors of adrenal epinephrine and norepinephrine in vivo. Biochim. Biophys. Acta 20:48-52. https://doi.org/10.1016/0006-3002(56)90261-X.

van der Drift, S., M. Houweling, J. Schonewille, A. Tielens, and R. Jorritsma. 2012. Protein and fat mobilization and associations with serum $\beta$-hydroxybutyrate concentrations in dairy cows. J. Dairy Sci. 95:4911-4920. https://doi.org/10.3168/jds.2011-4771.

Van Es, A. 1975. Feed evaluation for dairy cows. Livest. Prod. Sci. 2:95-107. https://doi.org/10.1016/0301-6226(75)90029-9. van Hoeij, R. J., J. Dijkstra, R. M. Bruckmaier, J. J. Gross, T. Lam, G. J. Remmelink, B. Kemp, and A. T. M. van Knegsel. 2017. The effect of dry period length and postpartum level of concentrate on milk production, energy balance, and plasma metabolites of dairy cows across the dry period and in early lactation. J. Dairy Sci. 100:5863-5879. https://doi.org/10.3168/jds.2016-11703.

Van Knegsel, A. T. M., M. J. W. Heetkamp, H. van den Brand, B. Kemp, and J. Dijkstra. 2012. Comparison between determined and calculated energy balance for dairy cows in early lactation. Page 248 in Book of Abstracts of the 63rd Annual Meeting of the European Federation of Animal Science (EAAP), Bratislava, Slovakia. Wageningen Academic Publishers, Wageningen, the Netherlands.

Wanders, R. J. A., H. R. Waterham, and S. Ferdinandusse. 2016. Metabolic interplay between peroxisomes and other subcellular organelles including mitochondria and the endoplasmic reticulum. Front. Cell Dev. Biol. 3:83. https://doi.org/10.3389/fcell.2015 .00083 .

Whitaker, D. A., E. J. Smith, G. O. da Rosa, and J. Kelly. 1993. Some effects of nutrition and management on the fertility of dairy cattle. Vet. Rec. 133:61-64. https://doi.org/10.1136/vr.133.3.61.

Whitton, P. D., L. M. Rodrigues, and D. A. Hems. 1978. Stimulation by vasopressin, angiotensin and oxytocin of gluconeogenesis in hepatocyte suspensions. Biochem. J. 176:893-898. https://doi.org/ 10.1042/bj1760893.

Wu, G., F. W. Bazer, R. C. Burghardt, G. A. Johnson, S. W. Kim, D. A. Knabe, P. Li, X. Li, J. R. McKnight, M. C. Satterfield, and T. E. Spencer. 2011. Proline and hydroxyproline metabolism: Implications for animal and human nutrition. Amino Acids 40:1053-1063. https://doi.org/https://dx.doi.org/10.1007\%2Fs00726-010-0715-z.

Wu, G., Z. Wu, Z. Dai, Y. Yang, W. Wang, C. Liu, B. Wang, J. Wang, and Y. Yin. 2013. Dietary requirements of "nutritionally non-essential amino acids" by animals and humans. Amino Acids 44:1107-1113. https://doi.org/10.1007/s00726-012-1444-2.

Xu, W., J. Vervoort, E. Saccenti, R. van Hoeij, B. Kemp, and A. van Knegsel. 2018. Milk metabolomics data reveal the energy balance of individual dairy cows in early lactation. Sci. Rep. 8:15828. https: //doi.org/10.1038/s41598-018-34190-4.

Zahra, L. C., T. F. Duffield, K. E. Leslie, T. R. Overton, D. Putnam, and S. J. LeBlanc. 2006. Effects of rumen-protected choline and monensin on milk production and metabolism of periparturient dairy cows. J. Dairy Sci. 89:4808-4818. https://doi.org/10.3168/ jds.S0022-0302(06)72530-9.

Zhou, Z., J. J. Loor, F. Piccioli-Cappelli, F. Librandi, G. E. Lobley, and E. Trevisi. 2016. Circulating amino acids in blood plasma during the peripartal period in dairy cows with different liver functionality index. J. Dairy Sci. 99:2257-2267. https://doi.org/ $10.3168 /$ jds.2015-9805

\section{ORCIDS}

Wei Xu • https://orcid.org/0000-0002-6370-7930

Jacques Vervoort (1) https://orcid.org/0000-0002-0091-5687

Bas Kemp ๑ https://orcid.org/0000-0002-9765-9105

Renny J. van Hoeij ๑ https://orcid.org/0000-0002-9131-8297

Ariette T. M. van Knegsel @ https://orcid.org/0000-0003-1959-3363 